Atmos. Chem. Phys., 13, 4681-4695, 2013

www.atmos-chem-phys.net/13/4681/2013/

doi:10.5194/acp-13-4681-2013

(C) Author(s) 2013. CC Attribution 3.0 License.

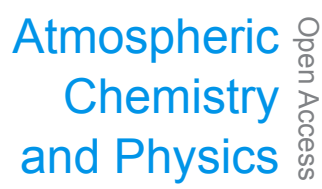

(c) (P)

\title{
Heterogeneous ice nucleation on phase-separated organic-sulfate particles: effect of liquid vs. glassy coatings
}

\author{
G. P. Schill and M. A. Tolbert \\ Cooperative Institute for Research in Environmental Sciences, University of Colorado, Boulder, Colorado, USA \\ Department of Chemistry and Biochemistry, University of Colorado, Boulder, Colorado, USA
}

Correspondence to: G. P. Schill (gregory.schill@colorado.edu) and M. A. Tolbert (tolbert@colorado.edu)

Received: 16 November 2012 - Published in Atmos. Chem. Phys. Discuss.: 3 December 2012

Revised: 20 March 2013 - Accepted: 3 April 2013 - Published: 6 May 2013

\begin{abstract}
Atmospheric ice nucleation on aerosol particles relevant to cirrus clouds remains one of the least understood processes in the atmosphere. Upper tropospheric aerosols as well as sub-visible cirrus residues are known to be enhanced in both sulfates and organics. The hygroscopic phase transitions of organic-sulfate particles can have an impact on both the cirrus cloud formation mechanism and resulting cloud microphysical properties. In addition to deliquescence and efflorescence, organic-sulfate particles are known to undergo another phase transition known as liquid-liquid phase separation. The ice nucleation properties of particles that have undergone liquid-liquid phase separation are unknown.

Here, Raman microscopy coupled with an environmental cell was used to study the low temperature deliquescence, efflorescence, and liquid-liquid phase separation behavior of $2: 1$ mixtures of organic polyols (1,2,6-hexanetriol and $1: 1$ 1,2,6-hexanetriol +2,2,6,6tetrakis(hydroxymethyl)cyclohexanol) and ammonium sulfate from 240-265 K. Further, the ice nucleation efficiency of these organic-sulfate systems after liquid-liquid phase separation and efflorescence was investigated from $210-235 \mathrm{~K}$. Raman mapping and volume-geometry analysis indicate that these particles contain solid ammonium sulfate cores fully engulfed in organic shells. For the ice nucleation experiments, we find that if the organic coatings are liquid, water vapor diffuses through the shell and ice nucleates on the ammonium sulfate core. In this case, the coatings minimally affect the ice nucleation efficiency of ammonium sulfate. In contrast, if the coatings become semi-solid or glassy, ice instead nucleates on the organic shell. Consistent with recent findings that glasses can be efficient ice nuclei, the phase-
\end{abstract}

separated particles are nearly as efficient at ice nucleation as pure crystalline ammonium sulfate.

\section{Introduction}

Cirrus clouds are ubiquitous in the upper troposphere and are known to have a large effect on the Earth's climate. For example, it has been shown that sub-visible cirrus clouds are present in the tropical tropopause layer (TTL) $50-80 \%$ of the time (Jensen et al., 2010). These clouds are of atmospheric importance because they can dehydrate air ascending through the TTL and, therefore, effectively regulate stratospheric humidity. Despite their ubiquity in the upper troposphere, ice cloud formation remains one of the least understood processes in the atmosphere and one of the largest uncertainties in the prediction of climate change (Forster, 2007). This is in large part due to the fact that particles available for ice nucleation are complex and that ice number concentrations are low $\left(\sim 1\right.$ in $10^{5}$ particles in the upper troposphere nucleate ice, Rogers et al., 2001), making in situ measurements difficult. Recently, single particle measurements in the upper troposphere have shown that background aerosols as well as sub-visible cirrus residues are enhanced in sulfates and organics and have little aerosol typically assumed to be excellent ice nuclei (IN), like mineral dust (Froyd et al., 2009; Froyd et al., 2010). Furthermore, it was shown that the average organic fraction of these particles ranged from $30-80 \%$ by mass in the convective region as well as the TTL (Froyd et al., 2009). 
These measurements, however, do not provide any information about the phase state and/or the distribution of chemicals within these organic-sulfate particles. Thus, the identity of the ice nuclei in this region of the atmosphere is still uncertain.

The hygroscopic phase transitions of organic-sulfate aerosol can influence the ice nucleation mechanism. If the particles are in an aqueous liquid phase, they are expected to nucleate ice homogeneously. Here, a critical ice germ is formed within the aqueous matrix of a supercooled liquid droplet. Homogeneous nucleation has been studied extensively in the past and has been well parameterized (Koop et al., 2000). Conversely, if the organic-sulfate particles are crystalline or amorphous solids, then they can act as heterogeneous ice nuclei. Here a foreign surface acts as a catalyst for ice germ formation. Previously, it was thought that homogeneous nucleation dominated cirrus cloud formation; however, combined field (Lawson et al., 2008; Kramer et al., 2009) and modeling studies (Jensen et al., 2010) have indicated that ice number and ice size distributions in the upper troposphere are sometimes better explained by heterogeneous nucleation.

Recently, it has been shown that mixed organic-sulfate particles can undergo another hygroscopic phase transition termed liquid-liquid phase separation (LLPS) (Marcolli and Krieger, 2006; Ciobanu et al., 2009). Here the inorganic component ammonium sulfate effectively salts out the less soluble organic components. Bertram et al. (2011) have shown that if the organic component of mixed organic-sulfate particles has an $\mathrm{O}: \mathrm{C}$ ratio $<0.7$, then it will generally phase separate; moreover, it has been shown that complex organicsulfate particles studied by Song et al. (2012), consisting of three separate dicarboxylic acids, always phase separated, as long as their combined $\mathrm{O}: \mathrm{C}$ ratio was $<0.7$. LLPS has also been observed with real-world organic-sulfate particles collected in the Atlanta, GA region (You et al., 2012). Finally, it has been shown that particles that have undergone LLPS minimally affect the deliquescence and efflorescence behavior of ammonium sulfate (Bertram et al., 2011; Smith et al., 2011).

Past work has shown that phase-separated particles containing two liquids can assume a number of partially engulfed morphologies (Kwamena et al., 2010; Reid et al., 2011). Partial engulfment has also been shown for mixed organic-sulfate particles that have undergone LLPS and subsequently effloresce (Song et al., 2012). However, it has been shown from $2 \mathrm{D}$ projections that many phase-separated, effloresced organic-sulfate systems assume a fully engulfed coreshell morphology, with an evenly thick organic coating and a crystalline ammonium sulfate core (Ciobanu et al., 2009; Bertram et al., 2011; Song et al., 2012). There have been many studies looking at the effects of organic coatings on the efficiency of ice nucleation. Möhler et al. (2008) found that coating Arizona test dust (ATD) and illite dust particles with secondary organic material (SOM) produced by the ozonlysis of $\alpha$-pinene required a higher supersaturation to nucleate ice than for the bare dust particles at temperatures between 205 and $210 \mathrm{~K}$. Koehler et al. (2010) observed similar results for coating ATD particles with SOM from the ozonolysis of $\alpha$-pinene for temperatures between 218 and $233 \mathrm{~K}$. In contrast, Wise et al. (2010) have shown that coating ammonium sulfate with palmitic acid minimally affected the ice nucleation efficacy of ammonium sulfate over a similar temperatures range to Koehler et al. (2010). Raman analysis of these particles, however, revealed that this behavior could be attributed to uneven coating by the organic material. Thus, partial coatings are shown to minimally affect the ice nucleation behavior of their cores; it is not clear, however, if full organic coatings would inhibit ice nucleation by ammonium sulfate.

Generally, ambient organic material has been anticorrelated with ice nucleation efficacy (Cziczo et al., 2004; Baustian et al., 2012a); some crystalline subsets, however, of organic aerosol may very well be efficient ice nuclei (Zobrist et al., 2006; Kanji et al., 2008; Schill and Tolbert, 2012). Real organic aerosol will most likely be composed of thousands to hundreds of thousands of species (Goldstein and Galbally, 2007), and likely be in an amorphous liquid, not crystalline state (Marcolli et al., 2004). Recently, there has been evidence that organic aerosol may in some cases be in semi-solid or solid amorphous states such as rubbers, gels, or glasses (Zobrist et al., 2008; Mikhailov et al., 2009; Virtanen et al., 2010; Koop et al., 2011). The work of Murray and coworkers has shown that, in general, highly oxygenated glassy organic aerosols are good heterogeneous ice nuclei, and can heterogeneously nucleate ice up to temperatures as high 218.5 K (Murray et al., 2010; Wilson et al., 2012). Further, the work of Knopf and coworkers suggests that chamber generated SOM can heterogeneously nucleate ice to temperatures as high as $240 \mathrm{~K}$ (Wang et al., 2012a) and that glassy organic coatings may be responsible for the efficient nucleation of ice by ambient particles collected in Mexico City and the Los Angeles Region (Wang et al., 2012b). Laboratory work in our group has shown glassy sugars are excellent heterogeneous ice nucleators (Baustian et al., 2012b). These combined works suggest that (semi-)solid amorphous organic coatings may enhance, not deactivate, the ice nucleation ability of phase-separated particles.

In the present work, we studied the low temperature deliquescence, liquid-liquid phase separation, and efflorescence behavior of mixed organic-sulfate particles using 1,2,6-hexanetriol or an equal mass ratio of 1,2,6hexanetriol/2,2,6,6-tetrakis(hydroxymethyl) cycohexanol as the organic species. Additionally, we studied the heterogeneous ice nucleation behavior of the pure organics and mixed organic-sulfate particles to help elucidate the role of phaseseparated particles in ice cloud formation. 


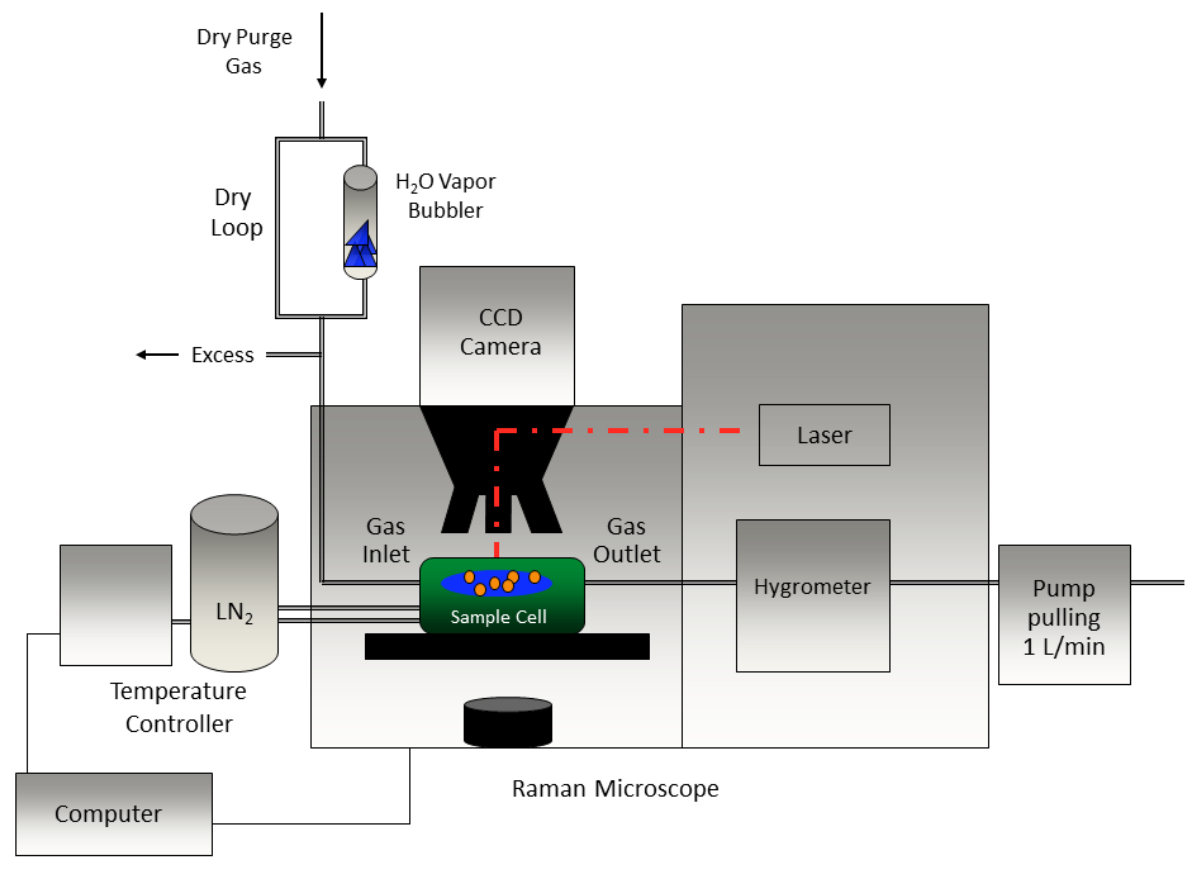

Fig. 1. Schematic representation of the Raman microscope setup.

\section{Experimental}

\subsection{Sample Preparation}

Aqueous solutions containing organics and organic-sulfate mixtures were prepared by dissolving pure substances in high purity water. Pure 1,2,6-hexanetriol (C6, molecular weight $=134.17 \mathrm{~g} \mathrm{~mol}^{-1}$ ) was made as a $1 \%$ solution. C6 was chosen because it has been previously shown to phase separate at $273 \mathrm{~K}$ for various organic-to-sulfate ratios (Bertram et al., 2011) and the conditions under which it forms a glass have been quantified (Zobrist et al., 2008). The other pure organic system consisted of a $1: 1$ mixture of C6 and 2,2,6,6-tetrakis(hydroxymethyl) cyclohexanol $\left(\mathrm{C} 10\right.$, molecular weight $=220.26 \mathrm{~g} \mathrm{~mol}^{-1}$, melting point $=123-127^{\circ} \mathrm{C}$ ), and was also made as a $1 \%$ solution. $\mathrm{C} 10$ was chosen because the conditions under which is forms a glass are also known (Zobrist et al., 2008). Further, C10 was chosen to act as a vitrifier in the $\mathrm{C} 6 / \mathrm{C} 10$ system because of its high molecular weight and high glass transition temperature $\left(T_{\mathrm{g}}, 258.6 \pm 5.2 \mathrm{~K}\right)$ in relation to $\mathrm{C} 6\left(T_{\mathrm{g}}=193.5 \pm 1.3 \mathrm{~K}\right)$. Each of these organic systems was also mixed with ammonium sulfate (AS) in a 2:1 organic-to-sulfate ratio. It should be noted that the $\mathrm{O}: \mathrm{C}$ ratio of pure $\mathrm{C} 6$ as well as the $\mathrm{C} 6 / \mathrm{C} 10$ mixture was 0.5 .

\subsection{Raman microscopy and environmental cell}

A schematic of the experimental system used to probe deliquescence, liquid-liquid phase separation, efflorescence, and ice nucleation is shown in Fig. 1. This system has been described in detail previously (Baustian et al., 2010; Wise et al., 2010). Briefly, a Nicolet Almega XR Dispersive Raman spectrometer has been outfitted with a Linkham THMS600 environmental cell and a Buck Research CR-1A chilledmirror hygrometer. Coupled to the spectrometer is an Olympus BX51 research grade optical microscope with 10x, 50x, and 100x magnification abilities.

Particles were deposited and viewed on a hydrophobically treated quartz disc (1 mm thick). To generate particles, a solution sample was aspirated into a Meinhard TR-50 glass concentric nebulizer. Nebulized droplets were directed at the quartz disc and allowed to coagulate into supermicron droplets. The sample disc was then transferred into the environmental cell and exposed to a low humidity environment. This evaporated the water, resulting in organic/AS droplets ranging from 1 to $40 \mu \mathrm{m}$ in lateral diameter.

The temperature $(T)$ of the particles was controlled with a Linkham TMS94 automated temperature controller. The temperature controller was calibrated against the melting point of ice, the deliquescence relative humidity (DRH) of $\mathrm{NaCl}$, and the ferroelectric phase transition of ammonium sulfate as described by Baustian et al. (2010), which yielded an uncertainty in $T$ of $< \pm 0.2 \mathrm{~K}$. Water vapor inside the cell was controlled by continuously flowing dry and humidified 

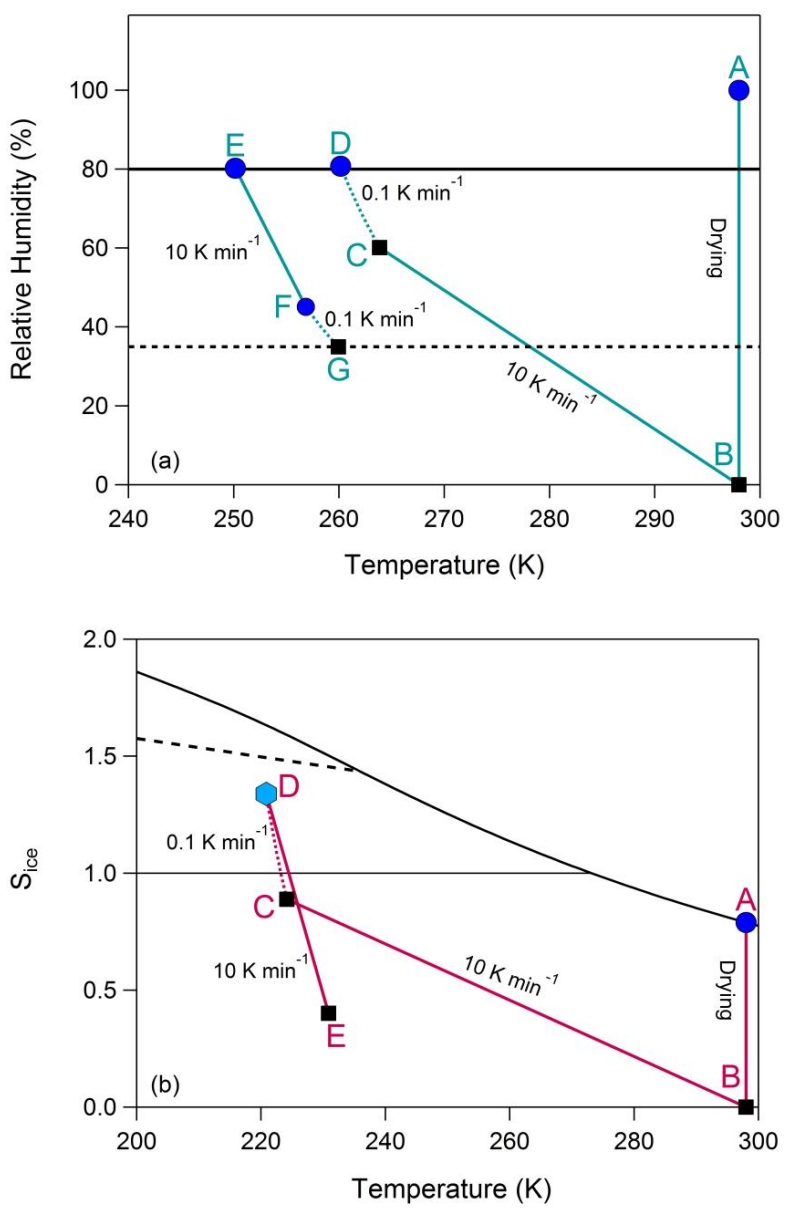

Fig. 2. Experimental trajectories for (a) deliquescence/efflorescence and (b) ice nucleation shown in relative humidity and ice saturation ratio $\left(S_{\text {ice }}\right)$ space, respectively. Each trajectory line has been labeled with an experimental heating/cooling rate. The solid and dashed black lines in (a) correspond to the deliquescence and efflorescence RH of ammonium sulfate, respectively. The thick solid, dashed, and thin solid black lines in (b) correspond to water saturation, the $S_{\text {ice values for homogenous nucleation of an aqueous }}$ droplet, and ice saturation, respectively. The capital letters in the panels indicate points that are of special interest; see text for details.

$\mathrm{N}_{2}$. At the exit of the cell, the CR-1A hygrometer measures dew point with an accuracy of $\pm 0.15 \mathrm{~K}$. The relative humidity with respect to water and ice experienced by the particles was derived from $T$ and the dew point employing the parameterizations of Murphy and Koop (2005). A Gast mechanical diaphragm pump ensured that the flow through the system was kept constant at $1 \mathrm{~L} \mathrm{~min}^{-1}$.

In the present study, both individual Raman spectra and spectral maps were acquired on a point-by-point manner. A frequency-doubled $\mathrm{Nd}$ : YAG laser operating at $532 \mathrm{~nm}$ was used for molecular excitation. Spectra were obtained using 50x and 100x objectives, which have diffraction limited spot sizes of 1.3 and $1.1 \mu \mathrm{m}$, respectively (Everall, 2010). Spectra were collected from $150-4000 \mathrm{~cm}^{-1}$, with a typical spectral resolution of $\sim 2-4 \mathrm{~cm}^{-1}$. Raman mapping was utilized to gather information about the spatial distribution of chemicals within individual particles. Raman line and 2D maps were acquired by taking a spectrum every $1 \mu \mathrm{m}$ in the $\mathrm{Y}$ and $\mathrm{XY}$ directions, respectively. An automated mapping program and high-precision motorized stage ensured accurate particle mapping.

\subsection{Deliquescence, liquid-liquid phase separation, and efflorescence experiments}

Figure 2a shows the experimental trajectory of a typical deliquescence experiment. A typical deliquescence experiment was started by exposing wet impacted particles (point A) to $\sim 0 \%$ relative humidity $(\mathrm{RH})$ at $298 \mathrm{~K}$ for at least 10 minutes to ensure that all particles were effloresced and completely dry (point B). In each experiment, a collection of 10 to 20 random particles were monitored visually under 50x magnification using the video output from a CCD (charge coupled device) camera mounted on the optical microscope. The relative humidity experienced by the particles in the environmental cell was controlled by keeping a constant dew point and steadily decreasing $T$. Specifically, after the dew point was stable for $10 \mathrm{~min}, T$ was decreased at a rate of $10 \mathrm{~K} \mathrm{~min}^{-1}$ from room temperature until $\mathrm{RH} \approx 60 \%$ (point $\mathrm{C}$ ); the sample was then cooled at a rate of $0.1 \mathrm{~K} \mathrm{~min}^{-1}$, corresponding to a change in RH of approximately $0.6 \% \mathrm{~min}^{-1}$, until deliquescence was observed visually (point D). An example of a deliquesced particle is shown in Fig. 3. Raman spectroscopy was used to verify deliquescence had occurred. Spectra were taken at the center and edge of particles to ensure that the particles were well mixed. Typical spectra of a deliquesced C6/AS particle can be seen in Fig. 3a and b. The main features of the spectrum are a sharp peak at $972 \mathrm{~cm}^{-1}$ (due to the symmetric stretching mode of $\mathrm{SO}_{4}^{2-}$ ), a broad band centered at $2900 \mathrm{~cm}^{-1}$ (due to the $\mathrm{C}-\mathrm{H}$ stretching vibrations of C6), and a broad band centered at $3400 \mathrm{~cm}^{-1}$ (due to the the symmetric and anti-symmetric O-H stretching modes of liquid water). The spectra taken at the center and edge of the particle are nearly identical, verifying that the particle is one homogeneous aqueous phase.

Liquid-liquid phase separation experiments (not shown in Fig. 2) started from deliquesced particles. The sample was warmed at a rate of $0.1 \mathrm{~K} \mathrm{~min}^{-1}$ until liquid-liquid phase separation occurred. Initial phase separation occurred in the form of schlieren (Ciobanu et al., 2009), which coalesce to form AS inclusions that diffuse into each other to eventually form two distinct phases. Raman spectroscopy was utilized to verify spectrally that the two distinct phases had formed. An image of a phase-separated particle and its subsequent spectra can be seen in Fig. 3c and d. As shown, the inside phase is enhanced in ammonia, sulfate, and water peaks, while the outside phase is enriched in organic peaks. After two distinct 
phases had formed and were verified spectrally, the sample was cooled at a rate of $0.1 \mathrm{~K} \mathrm{~min}^{-1}$ to determine the separation relative humidity by increasing the RH. These particles then underwent similar visual and spectral analysis to ensure that the particle had merged back into one aqueous phase.

Figure 2a also shows the experimental trajectory of a typical effloresce experiment. Efflorescence experiments were conducted on particles that had already undergone deliquescence (point E). The particles were cooled at a rate of $10 \mathrm{~K} \mathrm{~min}^{-1}$ until RH was $\sim 45 \%$ (point F). Then, the particles were warmed at a rate of $0.1 \mathrm{~K} \mathrm{~min}^{-1}$ until efflorescence was observed visually (point $G$ ) and verified spectrally (Fig. 3e and f). Inside/outside spectra were taken to ensure that the particles remained in a core-shell configuration after efflorescence. An additional, broad peak centered at $3175 \mathrm{~cm}^{-1}$ (due to the $\mathrm{N}-\mathrm{H}$ stretching vibrations of the ammonium ion), previously masked by the broad water peak, also appears in the spectra of the effloresced core.

For all deliquescence, liquid-liquid phase separation, and efflorescence experiments, at least three experiments were performed at each temperature on at least two independent sets of particles. Error bars in RH and temperature are reported as one standard deviation.

\subsection{Ice nucleation experiments}

Figure $2 \mathrm{~b}$ shows the experimental trajectory of a typical ice nucleation experiment. Each ice nucleation experiment started by exposing wet impacted particles (point A) to $\sim 0 \%$ relative humidity to ensure all particles were effloresced and completely dry (point B). The ice saturation ratio $\left(S_{\text {ice }}=\right.$ $\mathrm{P}_{\mathrm{H}_{2} \mathrm{O}} / \mathrm{VP}_{\text {ice }}$ ) value over the particles in the environmental cell was controlled by keeping a constant dew point and steadily decreasing $T$. Specifically, after the dew point was held stable for at least $10 \mathrm{~min}, T$ was decreased from room temperature until $S_{\text {ice }} \approx 0.88$ (point C). The sample was then cooled at a rate of $0.1 \mathrm{~K} \mathrm{~min}^{-1}$, corresponding to a change in $S_{\text {ice }}$ of approximately $0.01 \mathrm{~min}^{-1}$, until the onset of ice (point D) was observed at the critical ice saturation ratio $\left(S_{\text {crit }}\right)$. This experimental procedure is essentially the same as the deliquescence experiment, but at lower temperatures; thus, in these experiments, depositional nucleation is only possible before deliquescence occurs. Ice nucleation was monitored at 10x magnification. Great care was taken to ensure that the first ice nucleation event was observed; if multiple events were observed, those points were omitted and the experiment repeated.

After the first ice event was observed, the 50x objective was used to verify the existence of ice both visually and spectrally. The presence of water-ice was marked by the emergence of a broad band centered near $3250 \mathrm{~cm}^{-1}$. Next, the ice was sublimed by increasing $T$ by $10 \mathrm{~K}$ (point $\mathrm{E}$ ) and then a line map of the resultant ice nuclei was taken. Finally, to test whether ice preactivation influenced these results, the sample was warmed to $298 \mathrm{~K}$ and dried to $\sim 0 \% \mathrm{RH}$ before the next

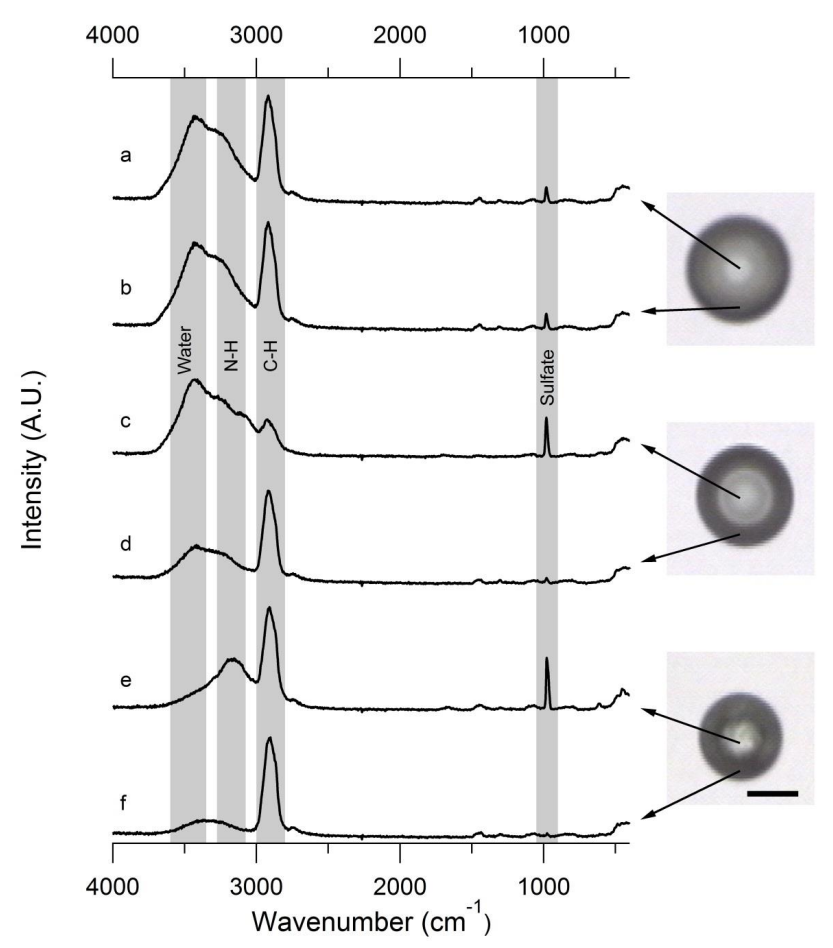

Fig. 3. Raman spectra of (a) the center of deliquesced C6/AS, (b) the edge of deliquesced C6/AS (c) the core of a C6/AS particle after LLPS, (d) the shell of a C6/AS particle after LLPS, (e) the core of a C6/AS particle after efflorescence, and (f) the shell of a C6/AS particle after efflorescence. The mixed particle used for Raman analysis is shown on the right. All measurements were taken at $260 \mathrm{~K}$. The size bar in the optical microscope image corresponds to $10 \mu \mathrm{m}$.

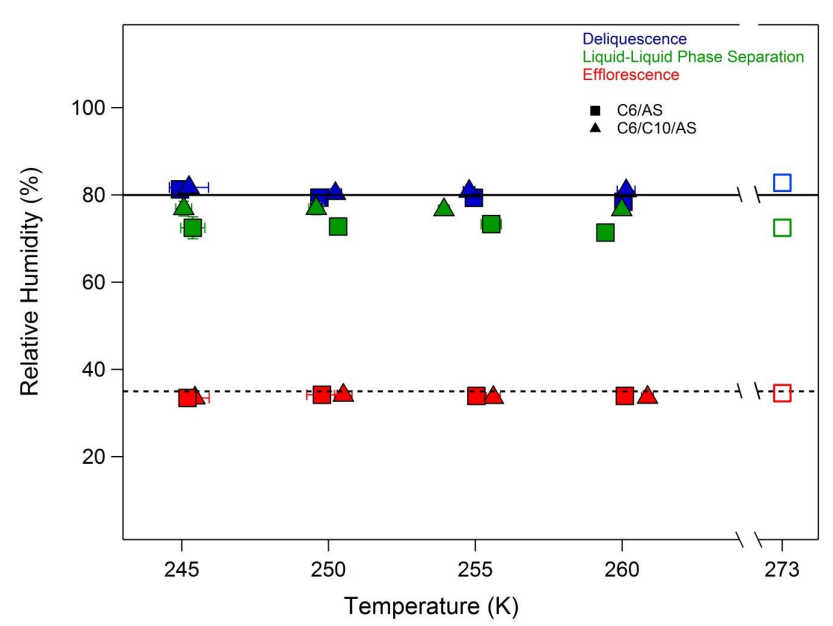

Fig. 4. Hygroscopic phase transitions of C6/AS and C6/C10/AS. For comparison, the DRH $(\mathrm{RH}=80 \%$, solid line) and ERH $(\mathrm{RH}=35 \%$, dashed line) lines for pure AS have been plotted. Experimental results from Bertram et al. (2011) for C6/AS in a 2.127 organic-to-sulfate ratio have also been plotted (open squares). Error bars in $\mathrm{RH}$ and temperature are reported as one standard deviation. 


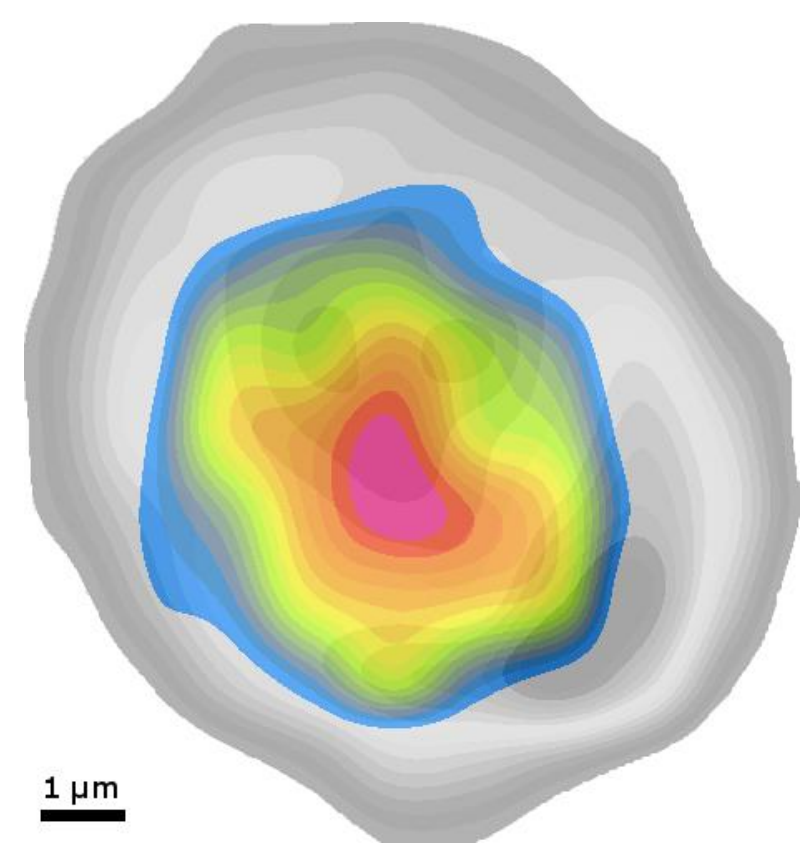

Fig. 5. Two-dimensional Raman spectral map of a phase-separated, effloresced C6/AS particle at $298 \mathrm{~K}$. The sulfate-containing region is shown as a color map where warmer colors refer to a higher intensity of the $\mathrm{SO}_{4}^{2-}$ peak $\left(972 \mathrm{~cm}^{-1}\right)$. The organic-containing region has undergone a similar analysis using the $\mathrm{C}-\mathrm{H}$ peak $\left(2900 \mathrm{~cm}^{-1}\right)$; however, this map has been gray-scaled for clarity. As shown, the particle is fully coated laterally.

experimental run. In our threshold freezing experiments, the same particle was never observed to be the first particle to nucleate ice more than once.

For all ice nucleation experiments at least three experiments were performed at each temperature on at least two independent sets of particles. Error bars in RH and temperature are reported as one standard deviation.

\section{Results}

\subsection{Low temperature deliquescence/efflorescence and liquid-liquid phase separation of organic- sulfate particles}

The results from the deliquescence/efflorescence and liquidliquid phase separation experiments are shown in Fig. 4. Also shown are lines corresponding to the DRH $(\mathrm{RH}=80 \%)$ and ERH (efflorescence RH; RH $=35 \%$ ) of pure AS (Martin, 2000). Comparing the deliquescence and efflorescence results from this work to those of pure AS, we find that liquid organic coatings minimally affect the deliquescence and efflorescence behavior of ammonium sulfate. This has been noted in the past for particles from 273 to $298 \mathrm{~K}$ (Bertram et al., 2011; Smith et al., 2011); however these results ex-
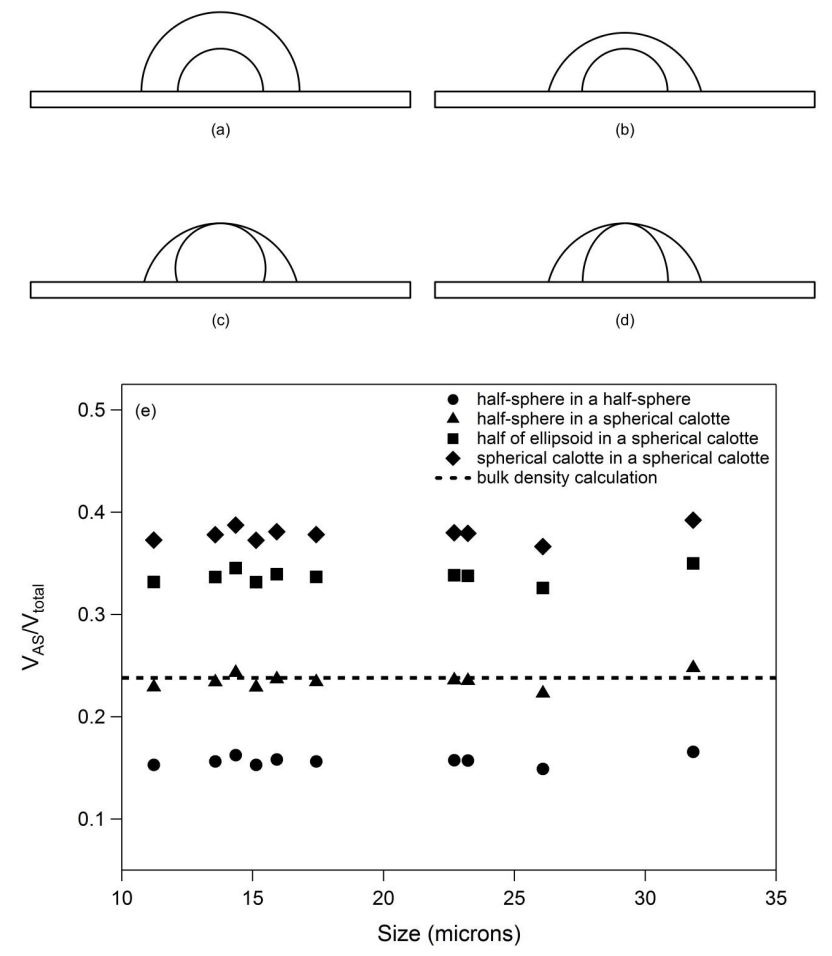

Fig. 6. Possible morphologies of particles after phase separation and efflorescence from Ciobanu et al. (2009): (a) half-sphere in a half-sphere, (b) half-sphere in a spherical calotte (contact angle of spherical calotte $=77^{\circ}$ ), (c) spherical calotte in a spherical calotte ( same height, contact angle of outer spherical calotte $=77^{\circ}$ ), and $(\mathbf{d})$ half of an ellipsoid in a spherical calotte (same height, contact angle of outer spherical calotte $=77^{\circ}$ ). Also shown (e) are the calculated ratios of effloresced AS volume to the total volume for each particle morphology compared to bulk volume ratio for particles from $10-35 \mu \mathrm{m}$ diameter used in the present study.

tend this general behavior to below the melting point of ice. We believe that this behavior can be explained by the fast diffusion of water vapor through the liquid organic coating. Differential scanning calorimetry experiments by Zobrist et al. (2008) have shown that C6 is expected to be in a liquid state at the DRH and ERH of AS for the temperatures explored in this work. The diffusion coefficient for a small molecule like water diffusing through a liquid organic matrix is $\sim 10^{-5}$ to $10^{-7} \mathrm{~cm}^{2} \mathrm{~s}^{-1}$ (Ciobanu et al., 2010; Shiraiwa et al., 2011). Thus, a small molecule like water should be able to diffuse through a $1 \mu \mathrm{m}$ liquid organic coating on the order of milliseconds to hundreds of milliseconds.

Similar to the data shown in Fig. $3 \mathrm{c}$ and d for C6/AS, the $\mathrm{C} 6 / \mathrm{C} 10 / \mathrm{AS}$ mixtures were also found to undergo liquidliquid phase separation at the temperatures explored in this study. Figure 4 includes the liquid-liquid phase separation $\mathrm{RH}$ (SRH) for these mixtures as a function of temperature. To the authors' knowledge, this is the first example of liquid-liquid phase separation at these temperatures; previous work was conducted at 273 to $298 \mathrm{~K}$. These results are 


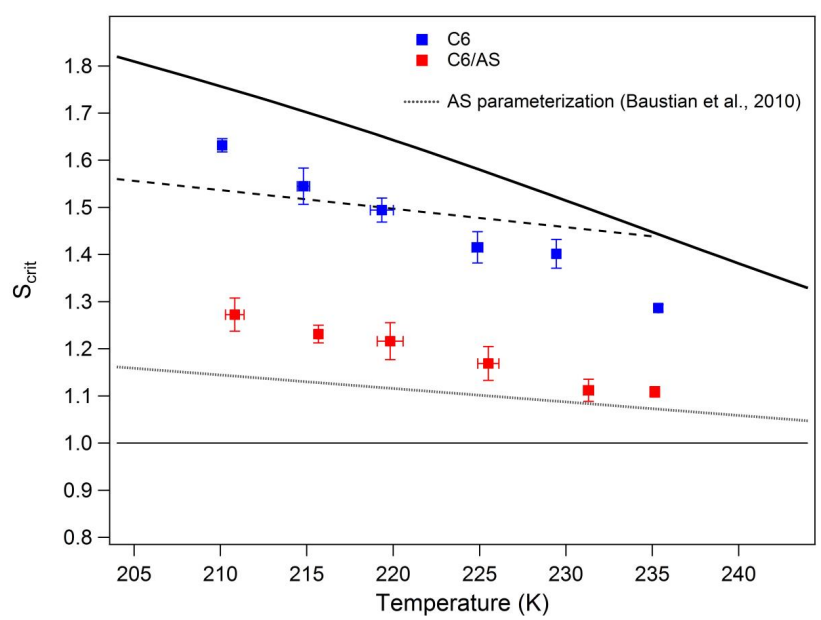

Fig. 7. $S_{\text {crit }}$ as a function of temperature for homogeneous freezing of pure C6 and immersion freezing of C6 by the AS core (C6/AS). The thick and thin solid lines refer to water and ice saturation respectively. The dashed line represents the $S_{\text {crit }}$ values for homogeneous nucleation of an aqueous droplet (Koop et al., 2000). Also included is a parameterization for depositional ice nucleation on pure AS from Baustian et al. (2010), as indicated by the hatched line. Error bars in $S_{\text {crit }}$ and temperature are reported as one standard deviation.

in agreement with Bertram et al. (2011), who have reported that binary organic and sulfate mixtures will generally phase separate if the $\mathrm{O}: \mathrm{C}$ ratio of the organic species is $<0.7$. Furthermore, the SRH of the mixtures in this study show no temperature dependence within error; indeed the SRH of the C6/AS mixture in a $2: 1$ organic-to-sulfate ratio in this work at $245 \mathrm{~K}$ is consistent with the SRH measurements of Bertram et al. (2011) taken at $273 \mathrm{~K}$ for C6/AS in a 2.127: 1 organic to sulfate ratio (Fig. 4).

\subsection{Particle morphology of effloresced organic- sulfate particles}

Previously, Wise et al. (2010) showed that mixed organicsulfate particles are efficient at nucleating ice due to incomplete organic coatings. There, it was concluded that any small portion of uncoated AS could act as the catalyst for new ice formation. To ensure that our particles were fully coated laterally, we utilized 2D Raman mapping to investigate several particles. An example 2D Raman map of an effloresced, phase-separated C6/AS particle can be seen in Fig. 5. Here, the sulfate containing region is mapped using the intensity of the $\mathrm{SO}_{4}^{2-}$ stretch $\left(972 \mathrm{~cm}^{-1}\right)$ in the Raman spectrum where warmer colors correspond to higher intensities. Similar analysis was done for the organic containing region using the intensity of the C-H stretch $\left(2900 \mathrm{~cm}^{-1}\right)$, however, the organic color map was grayscaled to differentiate between the organic and sulfate containing regions. Thus, for a phaseseparated $9 \mu \mathrm{m}$ particle we see that it will consist of an ap- proximately $6 \mu \mathrm{m}$ AS core surrounded by $\sim 1-3 \mu \mathrm{m}$ of an organic coating at all points.

Unfortunately, the present experimental setup gives only the top view of the particles and yields no quantitative information about the side view. To determine the threedimensional morphology of the particle and ensure that no portion of the effloresced ammonium sulfate core was exposed, we used a volume-geometry analysis similar to Ciobanu et al. (2009) to reconstruct the particle shape on the experimental substrate. To do so, we determined the contact angle of several $2 \mu \mathrm{L}$ C6 droplets on the silanized quartz disc using ImageJ software (Schneider et al., 2012) at $298 \mathrm{~K}$. The average contact angle measured for these droplets was $77 \pm 3^{\circ}$. Using this value we were able to calculate the height of any droplet by measuring its lateral dimensions; however, this does not give us information about the configuration of the AS core. Thus, we assumed several possible arrangements put forth by Ciobanu et al. (2009) for two immiscible liquids (Fig. 6a-d). Two of these arrangements, spherical calotte in a spherical calotte (Fig. 6c) and half of an ellipsoid in a spherical calotte (Fig. 6d), constrained the AS core to have the same height as the organic shell; here a small portion of the AS core could be exposed. In the remaining two configurations, half-sphere in a half-sphere (Fig. 6a) and half-sphere in a spherical calotte (Fig. 6b), the AS core was fully engulfed in an organic shell. In cases b-d, the contact angle of the outer spherical calotte was assumed to be $77^{\circ}$. To determine which of these configurations was most likely, we measured the radius of the AS core and C6 shell to calculate the ratio of the volume of AS ( $\left.V_{\mathrm{AS}}\right)$ to the total volume $\left(V_{\text {total }}\right)$ for each arrangement. These calculations were done for ten particles ranging from 10-35 $\mu \mathrm{m}$ in diameter (Fig. 6e), which were diameters typical of ice nuclei in this work. We then calculated the experimental ratio $V_{\mathrm{AS}} / V_{\text {total }}$ using the $2: 1$ organic-to-sulfate mass ratio of the bulk solution and a bulk density of 1.106 and $1.77 \mathrm{~g} \mathrm{~cm}^{-3}$ for pure $\mathrm{C} 6$ and effloresced AS, respectively. As shown in Fig. 6e, the bulk density calculation $V_{\mathrm{AS}} / V_{\text {total }}$ matches best with the half-sphere in a spherical calotte configuration and is inconsistent with both configurations that constrain the inner and outer particles to the same height. Using this half-sphere in a spherical calotte morphology, the difference in heights between the top of the C6 calotte and the top of the effloresced AS half-sphere was determined for the particles in Fig. 6e and ranged from 1.3 to $3.6 \mu \mathrm{m}$. Thus, from these measurements, we conclude the particles used in this study are effloresced AS cores fully engulfed in organic shells.

\subsection{Ice nucleation experiments}

The ice nucleation behavior of the pure C6 and C6/AS system can be seen in Fig. 7. Also shown is a parameterization for depositional ice nucleation on pure AS from Baustian et al. (2010). As seen, pure C6 is a poor ice nucleus at all temperatures explored. Indeed, at the lower temperatures, C6 

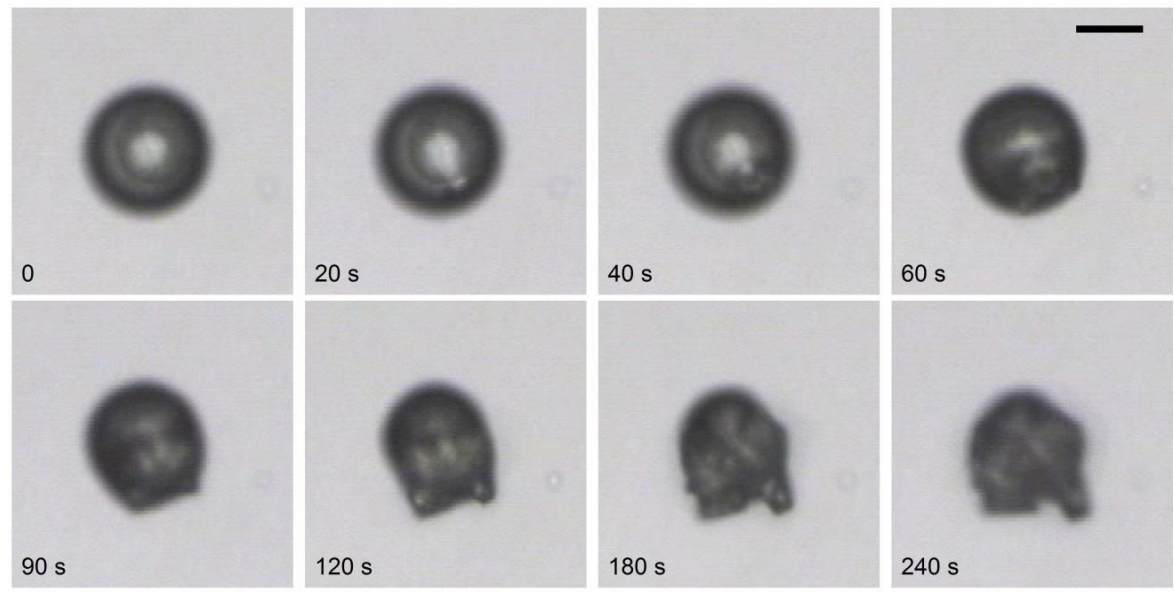

Fig. 8. Optical microscope images of ice nucleating on the effloresced AS core of a C6/AS particle that has undergone LLPS at $215 \mathrm{~K}$. Ice forms around $20 \mathrm{~s}$ at the AS-organic interface. As the ice grows beyond the dimensions of the organic shell, the shell spreads around it to reduce the surface tension over the entire system, indicating that the shell is a flowing liquid. The size bar corresponds to $10 \mu \mathrm{m}$.

tends to nucleate ice near or even above the Koop homogeneous freezing line. This is expected, as pure C6 is expected to be a liquid at each of the temperatures and RH probed in this study and the Koop line is for homogeneous nucleation from aqueous solutions. It should be noted that the slope of our homogeneous nucleation points is slightly skewed from the line of Koop et al. (2000) for a homogenous nucleation rate of $5 \times 10^{9} \mathrm{~cm}^{-3} \mathrm{~s}^{-1}$. This could be the result of our lowest temperature points being slightly outside of our temperature calibration curve as the lowest point in our calibration curve is the ferroelectric phase transition of ammonium sulfate at $223.1 \mathrm{~K}$; however, groups studying the homogeneous ice nucleation of sulfuric acid (Möhler et al., 2003) and organics (Wilson et al., 2012) using the AIDA (Aerosol Interactions and Dynamics in the Atmosphere) chamber have observed slopes similar to ours.

In contrast, for the C6/AS system we find that these phaseseparated particles are very efficient ice nuclei. In fact, these mixed organic-sulfate particles tend to nucleate ice nearly as efficiently as pure AS despite their full organic coatings. To elucidate why these phase-separated particles are such efficient ice nuclei, we took several videos at 50x magnification of ice nucleating on a larger particle. Select frames from one example video are shown in Fig. 8 and the entire video is available in the supplementary online material. The particle before ice nucleation is shown at $0 \mathrm{~s}$. At $20 \mathrm{~s}$, ice nucleates inside of the coated particle at the AS-organic interface (bottom right side of the inner part of particle). The initial ice crystal appears as a bright spot and grows outwardly from that point; by $80 \mathrm{~s}$, the ice has grown beyond the lateral dimensions of the organic coating. As the ice grows, the organic coating spreads over it to reduce the surface tension over the entire system. In the last frame, we see that the ice particle has now grown beyond the size of the original ice nucleus and is still stretching out the organic coating with it. This is more easily seen in Fig. 9, where a line map of the ice particle after ice has nucleated and grown is shown. As described previously, spectra are taken every $1 \mu \mathrm{m}$ in the Y direction; thus, every notch on the red line in the image of the particle corresponds to the location of a spectrum. The spectra are shown as a function of distance, and their intensities are shown as a color map, where warmer colors correlate to a higher intensity. From the line maps of the ammonia and sulfate stretches, we can see that an ammonium sulfate particle exists between $\sim 21$ and $30 \mu \mathrm{m}$. Around that particle, between $\sim 9$ and $35 \mu \mathrm{m}$, there is a large water-ice signature at $3250 \mathrm{~cm}^{-1}$. Correlated with the ice stretch is the $\mathrm{C}-\mathrm{H}$ stretch $\left(2900 \mathrm{~cm}^{-1}\right)$ that corresponds to the presence of C6. Thus, not only can we visually see that the liquid organic coating is spreading out as the ice grows, but we can verify that spectrally. Similar to our finding that liquid organic coatings minimally affect the deliquescence and efflorescence behavior of AS, we conclude that the water vapor must be diffusing through the liquid coating and ice is nucleating on the AS core. Thus, for the C6/AS particles, we are observing immersion freezing of the organic solution in contact with the AS cores. This explains why, even though these mixed particles are fully coated, these particles are almost as efficient ice nuclei as pure, effloresced AS in the deposition nucleation mode. To verify these findings with a more complex system with the same $\mathrm{O}: \mathrm{C}$ ratio, we conducted ice nucleation experiments on $\mathrm{C} 6 / \mathrm{C} 10$ and $\mathrm{C} 6 / \mathrm{C} 10 / \mathrm{AS}$ mixtures. The results of these experiments are shown in Fig. 10. At temperatures $\geq 220 \mathrm{~K}$, the $\mathrm{C} 6 / \mathrm{C} 10$ and $\mathrm{C} 6 / \mathrm{C} 10 / \mathrm{AS}$ systems have similar flow behavior to pure C6 and C6/AS. Furthermore, their ice nucleation behavior is qualitatively similar. Here, the pure organic system tends to be a poor IN; however, it is important to note that the pure organic mixture nucleates ice 


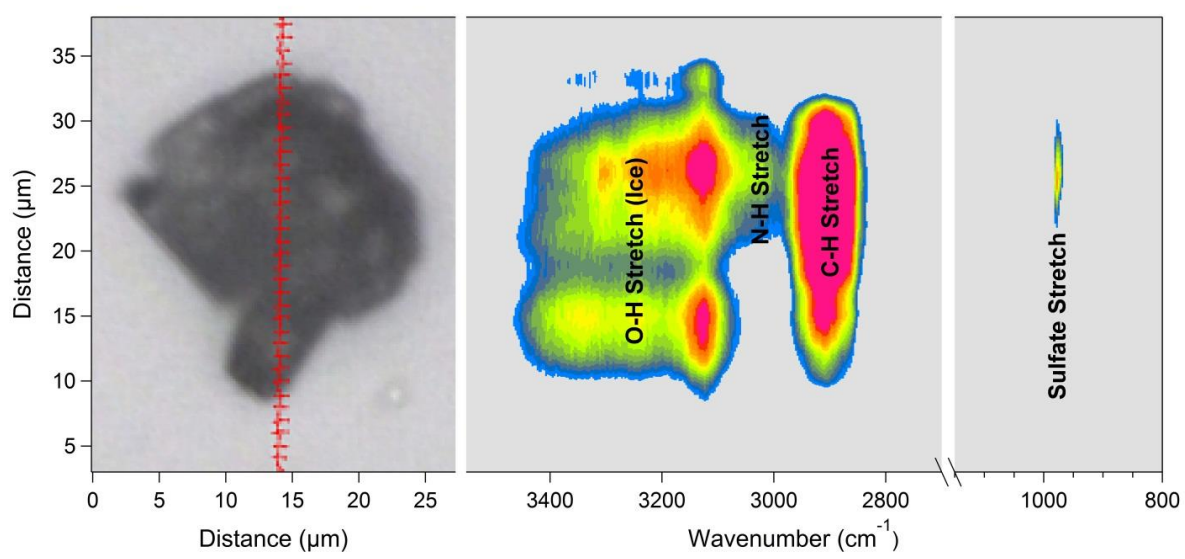

Fig. 9. Optical microscope image and corresponding Raman line map of C6/AS/ $\mathrm{H}_{2} \mathrm{O}$-ice at $215 \mathrm{~K}$. Raman spectral maps, taken every $1 \mu \mathrm{m}$ as indicated by the horizontal notches in the microscopic image, are shown as a function of distance and blended using a smoothing function. Raman intensities are shown as warm colors.

below the Koop homogeneous nucleation line and, therefore, the particles are likely acting as heterogeneous IN. For the $\mathrm{C} 6 / \mathrm{C} 10 / \mathrm{AS}$ system, the particles were again seen to nucleate ice almost as efficiently as pure AS in the depositional mode. Again, we find that at these temperatures we are observing immersion mode nucleation by the AS core. Thus, water vapor diffuses through the liquid organic shell, ice nucleates on the ammonium sulfate core, and the organic coating stretches out with the ice as it grows (not shown). Not only was this confirmed visually, but video and line map analysis similar to Figs. 8 and 9 were also performed (not shown).

At $215 \mathrm{~K}$, we found that ice nucleates differently for both $\mathrm{C} 6 / \mathrm{C} 10$ and C6/C10/AS. This is accompanied with an increase in ice nucleation efficiency of the pure C6/C10 system. Here, we found that ice nucleates at the organic-air interface for both the pure organic and the organic-sulfate system. This is shown in Fig. 11 for select frames, with the full nucleation movie available in the supplementary online material. Here, the images clearly show that ice is nucleating on the outside of the particle and not the inside. In addition, after ice nucleates on the organic, the organic shell does not spread out around the ice, suggesting that the organic shell is no longer a flowing liquid. This is verified by a line map taken of the ice particle (Fig. 12). Here we see there is a sulfate core between $\sim 16$ and $31 \mu \mathrm{m}$ surrounded by an organic coating ( $\sim 12.5$ to $37 \mu \mathrm{m}$ ); the ice, found between $\sim 5.5$ and $12.5 \mu \mathrm{m}$, however is not in contact with the sulfate core, and only grows from the organic shell. Furthermore, we see that the ice stretch is not correlated with the organic stretch. We believe that at these temperatures and relative humidities, the organic mixture is no longer a liquid, but rather a highly viscous (semi-)solid or glassy particle.

Despite the change in the heterogeneous nucleation site, the (semi-)solid or glassy organic IN in this work nucleate ice depositionally nearly as efficiently as pure AS. Although we are unable to probe this effect with our current experi- mental setup, we attribute this ice nucleation efficacy to the incorporation of water molecules into the glassy matrix. Prior to undergoing a glass transition, the organic will be in a liquid state that is in equilibrium with its surrounding water vapor (Mikhailov et al., 2009). Upon approaching the glass transition, the diffusion of water in the organic matrix will slow, and water could become entrenched in the viscous organic matrix (Zobrist et al., 2011). These entrenched water molecules could facilitate the formation of ice by providing a template similar to the crystal structure of ice (Pruppacher and Klett, 1996).

\subsection{Ice nucleation on solid amorphous organic particles above the glass transition line}

The experimental glass transition lines determined using differential scanning calorimetry by Zobrist et al. (2008) for aqueous glasses of C6 and C10 are shown in Fig. 13. The corresponding shaded areas around each of these $T_{\mathrm{g}}$ curves are the associated errors calculated using the parameterizations found in Zobrist et al. (2008). Also shown is the predicted $T_{\mathrm{g}}$ curve for a 1:1 mixture (by mass) of C6 and $\mathrm{C} 10$ using a mixing rule that depends on the molar masses and weight fractions of the individual polyols (Zobrist et al., 2008). Since this predicted curve does not have an associated error, the orange shaded region is simply bound by the pure $\mathrm{C} 6$ and $\mathrm{C} 10 T_{\mathrm{g}}$ curves. Plotted with the experimental and predicted $T_{\mathrm{g}}$ curves are the threshold ice nucleation points for C6/C10 and C6/C10/AS at 210 and $215 \mathrm{~K}$, where the organic particles/coatings were visually and spectrally shown to behave like highly viscous (semi-)solids or glasses (Figs. 11 and 12). As shown, these points are above the predicted glass transition line for a $1: 1$ mixture of C6 and C10.

To explain this behavior, we set out to approximate the viscosity of the $\mathrm{C} 6 / \mathrm{C} 10$ at the onset freezing conditions. The steep dependence of viscosity $(\eta)$ on temperature 


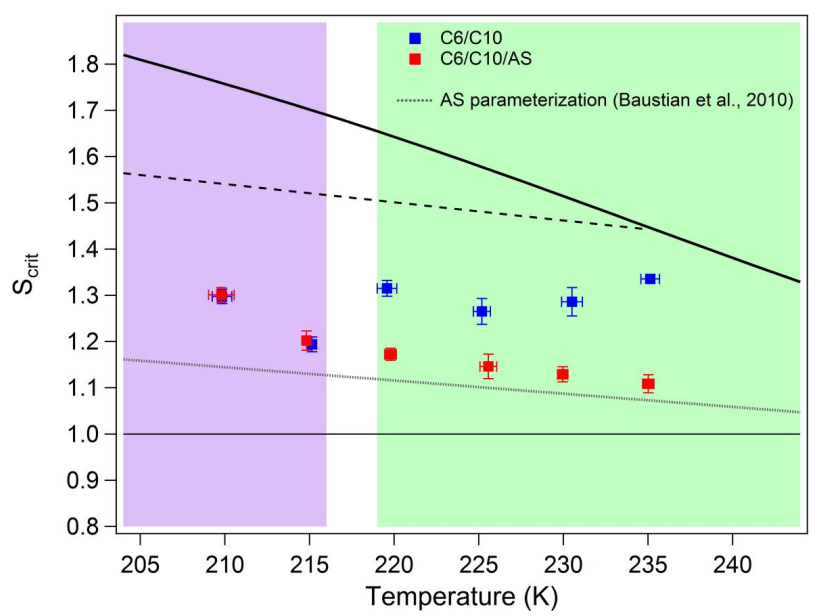

Fig. 10. $S_{\text {crit }}$ as a function of temperature for pure $\mathrm{C} 6 / \mathrm{C} 10$ and $\mathrm{C} 6 / \mathrm{C} 10 / \mathrm{AS}$. The thick and thin solid lines refer to water and ice saturation respectively. The dashed line represents the $S_{\text {crit values for }}$ homogeneous nucleation of an aqueous droplet (Koop et al., 2000). Also included is a parameterization for deposition ice nucleation on pure AS from Baustian et al. (2010), as indicated by the hatched line. The shaded regions split the experimental data into two viscosity regimes based on flow. Green shaded region: $\mathrm{C} 6 / \mathrm{C} 10$ observed to flow over growing ice crystal; here we observed immersion freezing of the organic solution in contact with the AS core. Purple shaded region: $\mathrm{C} 6 / \mathrm{C} 10$ observed to be in low-flowing, semi-solid state; here we observed depositional freezing on the C6/C10 shell. Error bars in $S_{\text {crit }}$ and temperature are reported as one standard deviation.

can be described by the Williams-Landel-Ferry equation (Debenedetti, 1996):

$\log (\eta)=\log \left(\eta_{T_{\mathrm{g}}}\right) \cdot\left[17.44\left(T-T_{\mathrm{g}}\right)\right] /\left[51.6+\left(T-T_{\mathrm{g}}\right)\right]$,

where $\eta_{T_{\mathrm{g}}}$ is the viscosity at the glass transition temperature, taken to be $10^{12} \mathrm{Pas}$. For the ice nucleation experiments at $215 \mathrm{~K}$, ice nucleated on $\mathrm{C} 6 / \mathrm{C} 10$ and $\mathrm{C} 6 / \mathrm{C} 10 / \mathrm{AS}$ at $70.7 \% \mathrm{RH}$. At this $\mathrm{RH}$, the predicted $T_{\mathrm{g}}$ for $1: 1 \mathrm{C} 6 / \mathrm{C} 10$ is $185 \mathrm{~K}$. Using Eq. (1), $\eta$ for $1: 1 \mathrm{C} 6 / \mathrm{C} 10$ is approximately $6.4 \times 10^{5} \mathrm{~Pa}$ s. Similarly, at $210 \mathrm{~K}$, ice nucleated on C6/C10 and $\mathrm{C} 6 / \mathrm{C} 10 / \mathrm{AS}$ at $74.0 \% \mathrm{RH}$, which correlates to a predicted $T_{\mathrm{g}}$ of $181 \mathrm{~K}$ and an $\eta$ of approximately $3.7 \times 10^{5} \mathrm{~Pa} \mathrm{~s}$. Thus, at 210 and $215 \mathrm{~K}$, pure $\mathrm{C} 6 / \mathrm{C} 10$ and the $\mathrm{C} 6 / \mathrm{C} 10$ coatings are considered amorphous semi-solids (Shiraiwa et al., 2011).

Zobrist et al. (2011) have shown that the diffusion coefficients for a small molecule like water diffusing through a glassy matrix at room temperature is $\sim 10^{-10} \mathrm{~cm}^{2} \mathrm{~s}^{-1}$; however, the diffusion constant was observed to decrease strongly with decreasing temperature. For example, at $200 \mathrm{~K}$, the diffusion coefficient for water through a glassy matrix drops 10 orders of magnitude to $10^{-20} \mathrm{~cm}^{2} \mathrm{~s}^{-1}$. Similar temperature dependence could be expected for highly viscous semi-solids above the glass transition. To the authors' knowledge, no such measurements have been made at temperatures relevant to this study. Shiraiwa et al. (2011) have measured the diffusion of the small molecule ozone through an amorphous semi-solid matrix at room temperature to be $\sim 10^{-7}$ to $10^{-9} \mathrm{~cm}^{2} \mathrm{~s}^{-1}$. If a similar, strong temperature dependence followed for amorphous semi-solids, the time for a water molecule to diffuse through a $1 \mu \mathrm{m}$ semi-solid shell may take much longer than that timescales of our ice nucleation experiments.

As mentioned before, the pure $\mathrm{C} 6 / \mathrm{C} 10$ mixture nucleated ice below the Koop homogeneous nucleation line from 220 $230 \mathrm{~K}$. Experiments similar to Fig. 8 have confirmed that these particles are able to flow and stretch with the growing ice particle (not shown). Analysis of the ice nuclei were also conducted to confirm that solid impurities, capable of acting as immerions mode nuclei were not present visually or spectrally. Although it is beyond the scope of this paper to ascertain the mechanism behind these results, the authors postulate that these particles may have the flow behavior of a liquid, but are still sufficiently viscous to provide a surface template for heterogeneous ice nucleation. To support this postulation, the viscosity of the pure organic mixture at the temperature and relative humidity of the ice nucleation event has been calculated using Eq. (1). For the 220, 225, and $230 \mathrm{~K}$ experiments ice formation was noted at approximately $79.8,80.2$, and $85.3 \%$ relative humidity with respect to water, respectively; this corresponds to an estimated viscosity of $5.2 \times 10^{3}, 1.5 \times 10^{3}$, and $1.2 \times 10^{2} \mathrm{Pas}$, respectively. These viscosities correlate to highly viscous liquids like ketchup (Koop et al., 2011). While these calculations provide only a rough estimation of these particles' viscosity, they suggest that the pure organic mixture at these temperatures and relative humidities might be viscous enough to provide a surface for heterogeneous ice nucleation.

Thus, for phase-separated organic-sulfate particles studied here, we find that if an organic coating is in its liquid state, then water vapor diffuses through the organic shell and nucleates on the AS core. If the organic coating become sufficiently viscous, however, then the water vapor can no longer diffuse through to the AS core, and ice nucleates on the organic shell. Two things should be noted here. One, the AS core does not seem to affect the ice nucleation behavior of the semi-solid organic; thus, the ice nucleation properties of these particles may depend almost entirely on the properties of the organic species. Two, for mixed organic-sulfate particles with liquid organic coating, the organic species minimally affects not only the deliquescence and efflorescence, but also the ice nucleation behavior of AS.

\section{Atmospheric implications}

Recently, several studies have underlined the importance of LLPS and its effect on the hygroscopic phase transitions of complex organic-sulfate aerosol. Song et al. (2012) have shown that mixtures of three dicarboxlyic acids and AS will 

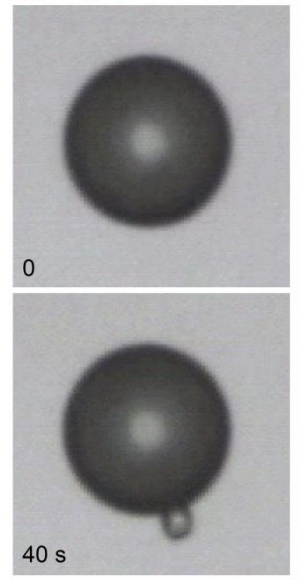
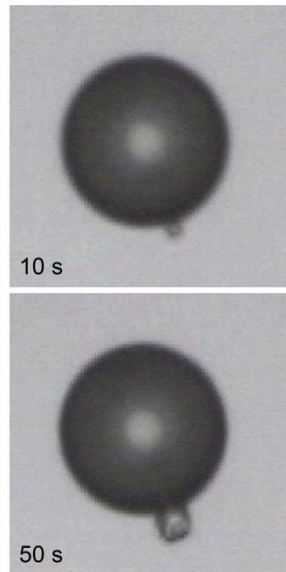
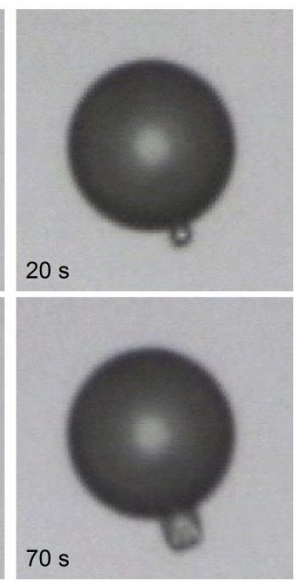

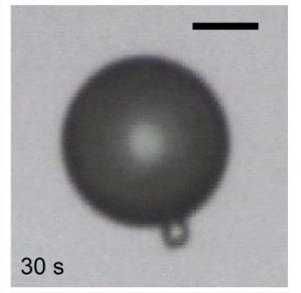

30

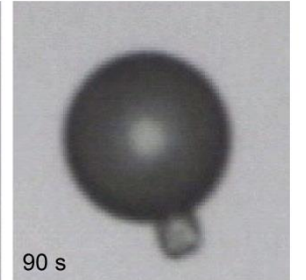

Fig. 11. Optical microscope images of ice nucleating on the shell of a C6/C10/AS particle that has undergone LLPS at $215 \mathrm{~K}$. Ice forms around $10 \mathrm{~s}$ at the organic-air interface. As the ice grows, the organic shell does not spread around it, indicating that it may be in a highly vicious (semi-)solid or glassy state. The size bar corresponds to $10 \mu \mathrm{m}$.
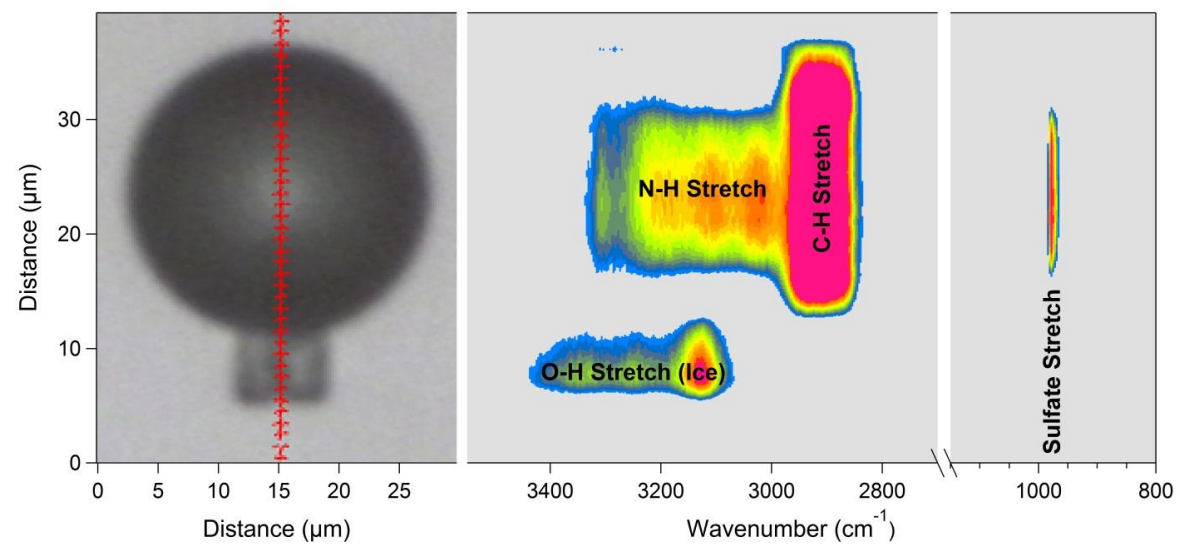

Fig. 12. Optical microscope image and corresponding Raman line map of C6/C10/AS/ $\mathrm{H}_{2} \mathrm{O}$-ice at $215 \mathrm{~K}$. Raman spectral maps, taken every $1 \mu \mathrm{m}$ as indicated by the horizontal notches in the microscopic image, are shown as a function of distance and blended using a smoothing function. Raman intensities are shown as warm colors.

undergo LLPS as long as their average $\mathrm{O}$ : $\mathrm{C}$ value was $<0.7$. It was also shown that these phase-separated particles minimally affect the deliquescence and efflorescence behavior of pure AS at $298 \mathrm{~K}$, which is in agreement with results from Bertram et al. (2011) taken at 273 and $290 \mathrm{~K}$. This behavior has also been seen with complex organic-sulfate particles at $298 \mathrm{~K}$ that were generated by condensing secondary organic aerosol (SOA) produced by dark ozonolysis of $\alpha$-pinene on AS seed particles (Smith et al., 2011). Here, the SOA was likely comprised of tens to hundreds of different organic molecules with average $\mathrm{O}: \mathrm{C}$ ratios of 0.39 and 0.44 as measured by the Aerodyne aerosol mass spectrometer (AMS).

The deliquescence and efflorescence behavior of these phase-separated particles is in stark contrast with uniphase organic-sulfate aerosol. For example, Marcolli et al. (2004) have shown that particles consisting of five organic acids and
AS that do not undergo LLPS, have a DRH of $36.4 \%$, and may inhibit efflorescence in these particles altogether. The authors concluded that ambient organic-sulfate aerosol may exist predominantly in a liquid state. Similar behavior was found for complex, chamber made SOA produced by the photo-oxidation of isoprene $(\mathrm{O}: \mathrm{C}$ ratios of 0.67 and 0.74$)$ condensed onto AS seed particles (Smith et al., 2012). Here, efflorescence was completely inhibited for organic volume fractions above 0.6 , and the DRH was as low as $40 \%$ for organic volume fractions approaching 0.9 . These results are in good agreement with the parameterization of Bertram et al. (2011), who have shown that phase separation is generally inhibited for organics with an $\mathrm{O}: \mathrm{C}$ ratio $>0.7$, and that large organic-to-sulfate ratios in uniphasic particles will depress both the DRH and ERH of organic-sulfate particles. 


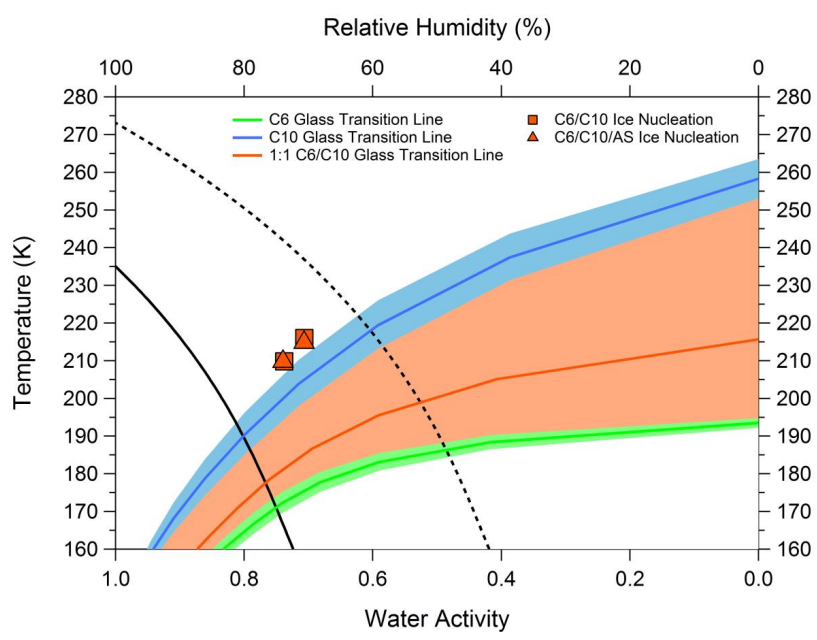

Fig. 13. The glass transition temperatures of $\mathrm{C} 6, \mathrm{C} 10$, and $1: 1$ C6/C10 shown as a function of water activity. The pure C6 and pure $\mathrm{C} 10$ glass transition curves are experimental data from Zobrist et al. (2008) using differential scanning calorimetry. The $1: 1$ C6/C10 glass transition curve was calculated using a mixing rule that depends on weight percent and molar mass. Also plotted are the conditions (temperature and $\mathrm{RH}$ ) for depositional ice nucleation on $\mathrm{C6} / \mathrm{C} 10$ and $\mathrm{C} 6 / \mathrm{C} 10 / \mathrm{AS}$, where the organic particle/coating was visually and spectrally shown to behave like a highly viscous (semi-)solid or glass. For clarity, the ice melting curve (black dashed line) and homogeneous freezing line (black solid line, Koop et al., 2000) are also plotted.

Many recent studies of ambient organic aerosol, however, show an average $\mathrm{O}: \mathrm{C}$ ratio of the organic fraction as measured by the AMS $<0.7$, even in heavily polluted areas like Mexico City (Aiken et al., 2008). Furthermore, factor analysis of 43 AMS data sets show that all semi-volatile oxygenated organic aerosol (SV-OOA) had an average $\mathrm{O}: \mathrm{C}$ ratio of $0.34 \pm 0.14$ and low-volatility OOA (LV-OOA) had an average $\mathrm{O}: \mathrm{C}$ ratio of $0.73 \pm 0.14$ ( $\mathrm{Ng}$ et al., 2010). Thus, all of the SV-OOA and a part of the LV-OOA fall into the O : C range where LLPS is expected. Indeed, You et al. (2012), have observed LLPS at $291 \mathrm{~K}$ in real-world, organic-sulfate particles collected the Atlanta, GA region. Finally, modeling work from Jensen et al. (2010) have shown that deliquesced ammonium sulfate particles that detrain from deep convective updrafts in the cold tropical tropopause layer can undergo efflorescence and be dry $20-80 \%$ of their lifetime; however, it is important to note that these results only hold if the organic coatings or mixtures do not inhibit efflorescence. These two combined effects indicate that effloresced, phase-separated particles can exist in the upper troposphere and could provide potential ice nuclei.

Our measurements show that phase separation in mixed organic-sulfate particles can occur at temperatures as low as $245 \mathrm{~K}$, and that liquid organic coatings minimally affect the ice nucleation efficiency of effloresced ammonium sulfate cores down to $210 \mathrm{~K}$. The heterogeneous ice nucleation efficiency of solid, effloresced ammonium sulfate has already been established (Abbatt et al., 2006; Baustian et al., 2010; Wise et al., 2010). Upon cooling or drying, atmospheric organics have been shown to undergo a glass transition (Koop et al., 2011), which often acts as a surface for heterogeneous ice nucleation (Wilson et al., 2012). In this work, C6/C10 was observed to nucleate ice at $S_{\text {ice }}=1.2$ to 1.3 from 210 to $215 \mathrm{~K}$. It should be noted, however, that the particles used in this study are larger than potential ice nuclei expected to be found in the upper troposphere (Froyd et al., 2009); in fact, particles used in this experiment have volumes a factor of hundreds to thousands larger than a typical accumulation mode particle. This could induce a size effect, especially with regard to the diffusion of water to the particle core. Since water diffusion times will be longer for thicker organic coatings/larger particles, the particles used in this study could exhibit glassy behavior at warmer temperatures than smaller particles typically found in the upper troposphere. Despite this size effect, these results are still in accordance with previous work on ice nucleation on simple organic glasses using a different size range of particles. For example, Murray et al. (2010) saw ice nucleate on glassy citric acid at $S_{\text {ice }}=1.23$ for $210 \mathrm{~K}$. In a follow-up study Wilson et al. (2012) saw ice nucleate on single component aqueous organic glasses at $S_{\text {ice }}=1.2$ to 1.55 from 190.8 to 218.5 K. Finally, Baustian et al. (2012b) have shown that ice nucleates on glassy glucose, sucrose, and citric acid between 210 and $235 \mathrm{~K}$ at $S_{\text {ice }}=1.1$ to 1.4 . Glassy, chamber generated SOM from the oxidation of naphthalene nucleated ice only slightly higher, from $S_{\text {ice }}=1.36$ to 1.52 , at $T<230 \mathrm{~K}$ (Wang et al., 2012a), but the authors state their minimum $S_{\text {ice }}$ values for this temperature range was 1.23 .

Thus, the combined ambient $\mathrm{O}: \mathrm{C}$ ratios, deliquescence, liquid-liquid phase separation, and efflorescence behavior of organic-sulfate mixtures, even when the organic fraction is multi-component, indicates that phase-separated particles could exist in the upper troposphere. Our measurements show that phase-separated, effloresced organic-sulfate particles can be efficient IN regardless of the phase state of the organic species, suggesting that these particle types are of significance for atmospheric ice nucleation.

\section{Conclusions}

We have shown that particles consisting of mixtures of AS with $\mathrm{C} 6$ and $\mathrm{C} 6 / \mathrm{C} 10$, both having an $\mathrm{O}: \mathrm{C}$ ratio of 0.5 , will phase separate at temperatures from 245 to $260 \mathrm{~K}$. At these temperatures, it was also seen that these organic coatings minimally affect both the deliquescence and efflorescence relative humidities of AS.

We have also shown that pure C6 is a poor ice nucleus, initiating the formation of ice near or above the Koop homogeneous nucleation line. Pure C6/C10 behaved similarly from 
220 to $235 \mathrm{~K}$; however, at $215 \mathrm{~K}$, this system became a more efficient ice nucleus. We attribute this to the particle moving from a liquid to a highly viscous (semi-)solid or glassy state. Ice nucleation on the particle exterior was confirmed both visually and spectrally using Raman line maps.

For the mixed organic-sulfate particles, we saw that if that particles underwent phase separation and efflorescence, and that if the coating was liquid, water vapor diffused through the liquid organic shell and nucleated on the AS core; here, we were observing immersion freezing of the organic shell by the AS core. If the organic coating becomes semi-solid or glassy, however, then water vapor may no longer be able to diffuse through the organic on timescales relevant to even the atmosphere; here, ice can depositionally freeze on the organic shell.

In conclusion, we find that phase-separated mixed organicsulfate particles can be excellent ice nuclei whether or not the organic coating is a liquid or a glass. If the coating is liquid, then the AS nucleates ice in the immersion mode at similar $S_{\text {ice }}$ as pure AS in the depositional mode. If, however, the coating becomes semi-solid or glassy, then it still may be good ice nucleus, possibly due to the retention of water molecules in the organic matrix.

\section{Supplementary material related to this article is available online at: http://www.atmos-chem-phys.net/13/ 4681/2013/acp-13-4681-2013-supplement.zip.}

Acknowledgements. This work was supported by the National Science Foundation under grants AGS1048536 and ATM0650023.

Edited by: O. Möhler

\section{References}

Abbatt, J. P. D., Benz, S., Cziczo, D. J., Kanji, Z., Lohmann, U., and Möhler, O.: Solid ammonium sulfate aerosols as ice nuclei: A pathway for cirrus cloud formation, Science, 313, 1770-1773, doi:10.1126/science.1129726, 2006.

Aiken, A. C., Decarlo, P. F., Kroll, J. H., Worsnop, D. R., Huffman, J. A., Docherty, K. S., Ulbrich, I. M., Mohr, C., Kimmel, J. R., Sueper, D., Sun, Y., Zhang, Q., Trimborn, A., Northway, M., Ziemann, P. J., Canagaratna, M. R., Onasch, T. B., Alfarra, M. R., Prevot, A. S. H., Dommen, J., Duplissy, J., Metzger, A., Baltensperger, U., and Jimenez, J. L.: O/C and OM/OC ratios of primary, secondary, and ambient organic aerosols with highresolution time-of-flight aerosol mass spectrometry, Environ. Sci. Technol., 42, 4478-4485, doi:10.1021/es703009q, 2008.

Baustian, K. J., Wise, M. E., and Tolbert, M. A.: Depositional ice nucleation on solid ammonium sulfate and glutaric acid particles, Atmos. Chem. Phys., 10, 2307-2317, doi:10.5194/acp-10-23072010, 2010.
Baustian, K. J., Cziczo, D. J., Wise, M. E., Pratt, K. A., Kulkarni, G., Hallar, A. G., and Tolbert, M. A.: Importance of aerosol composition, mixing state, and morphology for heterogeneous ice nucleation: A combined field and laboratory approach, J. Geophys. Res., 117, D06217, doi:10.1029/2011jd016784, 2012a.

Baustian, K. J., Wise, M. E., Jensen, E. J., Schill, G. P., Freedman, M. A., and Tolbert, M. A.: State transformations and ice nucleation in glassy or (semi-)solid amorphous organic aerosol, Atmos. Chem. Phys. Discuss., 12, 27333-27366, doi:10.5194/acpd12-27333-2012, 2012b.

Bertram, A. K., Martin, S. T., Hanna, S. J., Smith, M. L., Bodsworth, A., Chen, Q., Kuwata, M., Liu, A., You, Y., and Zorn, S. R.: Predicting the relative humidities of liquid-liquid phase separation, efflorescence, and deliquescence of mixed particles of ammonium sulfate, organic material, and water using the organic-to-sulfate mass ratio of the particle and the oxygen-tocarbon elemental ratio of the organic component, Atmos. Chem. Phys. Discuss., 11, 17759-17788, doi:10.5194/acpd-11-177592011, 2011.

Ciobanu, V. G., Marcolli, C., Krieger, U. K., Weers, U., and Peter, T.: Liquid-Liquid Phase Separation in Mixed Organic/Inorganic Aerosol Particles, J. Phys. Chem. A, 113, 10966-10978, doi:10.1021/jp905054d, 2009.

Ciobanu, V. G., Marcolli, C., Krieger, U. K., Zuend, A., and Peter, T.: Efflorescence of Ammonium Sulfate and Coated Ammonium Sulfate Particles: Evidence for Surface Nucleation, J. Phys. Chem. A, 114, 9486-9495, doi:10.1021/jp103541w, 2010.

Cziczo, D. J., DeMott, P. J., Brooks, S. D., Prenni, A. J., Thomson, D. S., Baumgardner, D., Wilson, J. C., Kreidenweis, S. M., and Murphy, D. M.: Observations of organic species and atmospheric ice formation, Geophys. Res. Lett., 31, 4, L12116, doi:10.1029/2004g1019822, 2004.

Debenedetti, P. G.: Metastable Liquids: Concepts and Principles, Princeton University Press, Princeton, NJ, 1996.

Everall, N. J.: Confocal Raman microscopy: common errors and artefacts, Analyst, 135, 2512-2522, doi:10.1039/c0an00371a, 2010.

Forster, P., Ramaswamy, V., Artaxo, P., Berntsen, T., Betts, R., Fahey, D. W., Haywood, J., Lean, J., Lowe, D. C., Myhre, G., Nganga, J., Prinn, R., Raga, G., Schulz, M., and Van Dorland, R.: Changes in atmospheric constituents and radiative forcing, in: Climate Change 2007: The Physical Science Basis, Contribution of Working Group I to the Fourth Assessment Report of the Intergovernmental Panel on Climate Change, edited by: Solomon, S., Qin, D., Manning, M., Chen, Z., Marquis, M., Averyt, K. B., Tignor, M., and Miller, H. L., Cambridge Univ. Press, Cambridge, UK, 131-234, 2007.

Froyd, K. D., Murphy, D. M., Sanford, T. J., Thomson, D. S., Wilson, J. C., Pfister, L., and Lait, L.: Aerosol composition of the tropical upper troposphere, Atmos. Chem. Phys. Discuss., 9, 9399-9456, doi:10.5194/acpd-9-9399-2009, 2009.

Froyd, K. D., Murphy, D. M., Lawson, P., Baumgardner, D., and Herman, R. L.: Aerosols that form subvisible cirrus at the tropical tropopause, Atmos. Chem. Phys., 10, 209-218, doi:10.5194/acp10-209-2010, 2010.

Goldstein, A. H. and Galbally, I. E.: Known and unexplored organic constituents in the earth's atmosphere, Environ. Sci. Technol., 41, 1514-1521, 2007. 
Jensen, E. J., Pfister, L., Bui, T.-P., Lawson, P., and Baumgardner, D.: Ice nucleation and cloud microphysical properties in tropical tropopause layer cirrus, Atmos. Chem. Phys., 10, 1369-1384, doi:10.5194/acp-10-1369-2010, 2010

Kanji, Z. A., Florea, O., and Abbatt, J. P. D.: Ice formation via deposition nucleation on mineral dust and organics: dependence of onset relative humidity on total particulate surface area, Environ. Res. Lett., 3, 025004, doi:10.1088/1748-9326/3/2/025004, 2008.

Koehler, K. A., Kreidenweis, S. M., DeMott, P. J., Petters, M. D., Prenni, A. J., and Möhler, O.: Laboratory investigations of the impact of mineral dust aerosol on cold cloud formation, Atmos. Chem. Phys., 10, 11955-11968, doi:10.5194/acp10-11955-2010, 2010.

Koop, T., Luo, B. P., Tsias, A., and Peter, T.: Water activity as the determinant for homogeneous ice nucleation in aqueous solutions, Nature, 406, 611-614, doi:10.1038/35020537, 2000.

Koop, T., Bookhold, J., Shiraiwa, M., and Pöschl, U.: Glass transition and phase state of organic compounds: dependency on molecular properties and implications for secondary organic aerosols in the atmosphere, Phys. Chem. Chem. Phys., 13, 19238-19255, doi:10.1039/c1cp22617g, 2011.

Kramer, M., Schiller, C., Afchine, A., Bauer, R., Gensch, I., Mangold, A., Schlicht, S., Spelten, N., Sitnikov, N., Borrmann, S., de Reus, M., and Spichtinger, P.: Ice supersaturations and cirrus cloud crystal numbers, Atmos. Chem. Phys., 9, 3505-3522, 2009,

http://www.atmos-chem-phys.net/9/3505/2009/.

Kwamena, N. O. A., Buajarern, J., and Reid, J. P.: Equilibrium Morphology of Mixed Organic/Inorganic/Aqueous Aerosol Droplets: Investigating the Effect of Relative Humidity and Surfactants, J. Phys. Chem. A, 114, 5787-5795, doi:10.1021/jp1003648, 2010.

Lawson, R. P., Pilson, B., Baker, B., Mo, Q., Jensen, E., Pfister, L., and Bui, P.: Aircraft measurements of microphysical properties of subvisible cirrus in the tropical tropopause layer, Atmos. Chem. Phys., 8, 1609-1620, 2008,

http://www.atmos-chem-phys.net/8/1609/2008/.

Marcolli, C. and Krieger, U. K.: Phase changes during hygroscopic cycles of mixed organic/inorganic model systems of tropospheric aerosols, J. Phys. Chem. A, 110, 1881-1893, doi:10.1021/jp0556759, 2006.

Marcolli, C., Luo, B. P., and Peter, T.: Mixing of the organic aerosol fractions: Liquids as the thermodynamically stable phases, J. Phys. Chem. A, 108, 2216-2224, doi:10.1021/jp0360801, 2004.

Martin, S. T.: Phase transitions of aqueous atmospheric particles, Chem. Rev., 100, 3403-3453, doi:10.1021/cr990034t, 2000.

Mikhailov, E., Vlasenko, S., Martin, S. T., Koop, T., and Pöschl, U.: Amorphous and crystalline aerosol particles interacting with water vapor: conceptual framework and experimental evidence for restructuring, phase transitions and kinetic limitations, Atmos. Chem. Phys., 9, 9491-9522, doi:10.5194/acp-9-9491-2009, 2009

Möhler, O., Stetzer, O., Schaefers, S., Linke, C., Schnaiter, M., Tiede, R., Saathoff, H., Krämer, M., Mangold, A., Budz, P., Zink, P., Schreiner, J., Mauersberger, K., Haag, W., Kärcher, B., and Schurath, U.: Experimental investigation of homogeneous freezing of sulphuric acid particles in the aerosol chamber AIDA, Atmos. Chem. Phys., 3, 211-223, doi:10.5194/acp-3-211-2003, 2003.
Möhler, O., Benz, S., Saathoff, H., Schnaiter, M., Wagner, R., Schneider, J., Walter, S., Ebert, V., and Wagner, S.: The effect of organic coating on the heterogeneous ice nucleation efficiency of mineral dust aerosols, Environ. Res. Lett., 3, 025007 , doi:10.1088/1748-9326/3/2/025007, 2008.

Murphy, D. M. and Koop, T.: Review of the vapour pressures of ice and supercooled water for atmospheric applications, Q. J. R. Meteorol. Soc., 131, 1539-1565, doi:10.1256/qj.04.94, 2005.

Murray, B. J., Wilson, T. W., Dobbie, S., Cui, Z. Q., Al-Jumur, S., Möhler, O., Schnaiter, M., Wagner, R., Benz, S., Niemand, M., Saathoff, H., Ebert, V., Wagner, S., and Karcher, B.: Heterogeneous nucleation of ice particles on glassy aerosols under cirrus conditions, Nat. Geosci., 3, 233-237, doi:10.1038/ngeo817, 2010.

Ng, N. L., Canagaratna, M. R., Zhang, Q., Jimenez, J. L., Tian, J., Ulbrich, I. M., Kroll, J. H., Docherty, K. S., Chhabra, P. S., Bahreini, R., Murphy, S. M., Seinfeld, J. H., Hildebrandt, L., Donahue, N. M., DeCarlo, P. F., Lanz, V. A., Prevot, A. S. H., Dinar, E., Rudich, Y., and Worsnop, D. R.: Organic aerosol components observed in Northern Hemispheric datasets from Aerosol Mass Spectrometry, Atmos. Chem. Phys., 10, 46254641, doi:10.5194/acp-10-4625-2010, 2010.

Pruppacher, H. R. and Klett, J. D.: Microphysics of clouds and precipitation, Kluwer Academic Publishers, Dordrecht, The Netherlands, 1996.

Reid, J. P., Dennis-Smither, B. J., Kwamena, N. O. A., Miles, R. E. H., Hanford, K. L., and Homer, C. J.: The morphology of aerosol particles consisting of hydrophobic and hydrophilic phases: hydrocarbons, alcohols and fatty acids as the hydrophobic component, Phys. Chem. Chem. Phys., 13, 15559-15572, doi:10.1039/c1cp21510h, 2011.

Rogers, D. C., DeMott, P. J., and Kreidenweis, S. M.: Airborne measurements of tropospheric ice-nucleating aerosol particles in the Arctic spring, J. Geophys. Res., 106, 15053-15063, doi:10.1029/2000jd900790, 2001.

Schill, G. P., and Tolbert, M. A.: Depositional Ice Nucleation on Monocarboxylic Acids: Effect of the O : C Ratio, J. Phys. Chem. A, 116, 6817-6822, doi:10.1021/jp301772q, 2012.

Schneider, C. A., Rasband, W. S., and Eliceiri, K. W.: NIH Image to ImageJ: 25 years of image analysis, Nat. Methods, 9, 671-675, doi:10.1038/nmeth.2089, 2012.

Shiraiwa, M., Ammann, M., Koop, T., and Pöschl, U.: Gas uptake and chemical aging of semisolid organic aerosol particles, Proc. Natl. Acad. Sci. U.S.A., 108, 11003-11008, doi:10.1073/pnas.1103045108, 2011.

Smith, M. L., Kuwata, M., and Martin, S. T.: Secondary Organic Material Produced by the Dark Ozonolysis of alphaPinene Minimally Affects the Deliquescence and Efflorescence of Ammonium Sulfate, Aerosol Sci. Technol., 45, 244-261, doi:10.1080/02786826.2010.532178, 2011.

Smith, M. L., Bertram, A. K., and Martin, S. T.: Deliquescence, efflorescence, and phase miscibility of mixed particles of ammonium sulfate and isoprene-derived secondary organic material, Atmos. Chem. Phys. Discuss., 12, 9903-9943, doi:10.5194/acpd-12-9903-2012, 2012.

Song, M., Marcolli, C., Krieger, U. K., Zuend, A., and Peter, T.: Liquid-liquid phase separation and morphology of internally mixed dicarboxylic acids/ammonium sulfate/water particles, Atmos. Chem. Phys., 12, 2691-2712, doi:10.5194/acp-12-2691- 
2012, 2012.

Virtanen, A., Joutsensaari, J., Koop, T., Kannosto, J., Yli-Pirila, P., Leskinen, J., Makela, J. M., Holopainen, J. K., Poeschl, U., Kulmala, M., Worsnop, D. R., and Laaksonen, A.: An amorphous solid state of biogenic secondary organic aerosol particles, Nature, 467, 824-827, doi:10.1038/nature09455, 2010.

Wang, B., Lambe, A. T., Massoli, P., Onasch, T. B., Davidovits, P., Worsnop, D. R., and Knopf, D. A.: The deposition ice nucleation and immersion freezing potential of amorphous secondary organic aerosol: Pathways for ice and mixed-phase cloud formation, J. Geophys. Res., 117, D16209, doi:10.1029/2012JD018063, 2012a.

Wang, B., Laskin, A., Roedel, T., Gilles, M. K., Moffet, R. C., Tivanski, A. V., and Knopf, D. A.: Heterogeneous ice nucleation and water uptake by field-collected atmospheric particles below $273 \mathrm{~K}$, J. Geophys. Res., 117, D00V19, doi:10.1029/2012JD017446, 2012b.

Wilson, T. W., Murray, B. J., Wagner, R., Möhler, O., Saathoff, H., Schnaiter, M., Skrotzki, J., Price, H. C., Malkin, T. L., Dobbie, S., and Al-Jumur, S. M. R. K.: Glassy aerosols with a range of compositions nucleate ice heterogeneously at cirrus temperatures, Atmos. Chem. Phys., 12, 8611-8632, doi:10.5194/acp-128611-2012, 2012.

Wise, M. E., Baustian, K. J., and Tolbert, M. A.: Internally mixed sulfate and organic particles as potential ice nuclei in the tropical tropopause region, Proc. Natl. Acad. Sci. U. S. A., 107, 66936698, doi:10.1073/pnas.0913018107, 2010.
You, Y., Renbaum-Wolff, L., Carreras-Sospedra, M., Hanna, S. J., Hiranuma, N., Kamal, S., Smith, M. L., Zhang, X. L., Weber, R. J., Shilling, J. E., Dabdub, D., Martin, S. T., and Bertram, A. K.: Images reveal that atmospheric particles can undergo liquidliquid phase separations, Proc. Natl. Acad. Sci. U. S. A., 109, 13188-13193, doi:10.1073/pnas.1206414109, 2012.

Zobrist, B., Marcolli, C., Koop, T., Luo, B. P., Murphy, D. M., Lohmann, U., Zardini, A. A., Krieger, U. K., Corti, T., Cziczo, D. J., Fueglistaler, S., Hudson, P. K., Thomson, D. S., and Peter, T.: Oxalic acid as a heterogeneous ice nucleus in the upper troposphere and its indirect aerosol effect, Atmos. Chem. Phys., 6, 3115-3129, 2006, http://www.atmos-chem-phys.net/6/3115/2006/.

Zobrist, B., Marcolli, C., Pedernera, D. A., and Koop, T.: Do atmospheric aerosols form glasses?, Atmos. Chem. Phys., 8, 52215244, 2008, http://www.atmos-chem-phys.net/8/5221/2008/.

Zobrist, B., Soonsin, V., Luo, B. P., Krieger, U. K., Marcolli, C., Peter, T., and Koop, T.: Ultra-slow water diffusion in aqueous sucrose glasses, Phys. Chem. Chem. Phys., 13, 3514-3526, doi:10.1039/c0cp01273d, 2011. 